\title{
Occupational health and safety disclosures in sustainability reports: an overview of trends among corporate leaders
}

Article

Accepted Version

Evangelinos, K., Fotiadis, S., Skouloudis, A., Khan, N., Konstantakopoulou, F., Nikolaou, I. and Lundy, S. (2018) Occupational health and safety disclosures in sustainability reports: an overview of trends among corporate leaders. Corporate Social Responsibility and Environmental Management, 25 (5). pp. 961-970. ISSN 1535-3966 doi: https://doi.org/10.1002/csr.1512 Available at https://centaur.reading.ac.uk/75505/

It is advisable to refer to the publisher's version if you intend to cite from the work. See Guidance on citing.

To link to this article DOI: http://dx.doi.org/10.1002/csr.1512

Publisher: Wiley

All outputs in CentAUR are protected by Intellectual Property Rights law, including copyright law. Copyright and IPR is retained by the creators or other copyright holders. Terms and conditions for use of this material are defined in the End User Agreement. 


\section{www.reading.ac.uk/centaur}

\section{CentAUR}

Central Archive at the University of Reading

Reading's research outputs online 


\title{
Occupational health and safety disclosures in sustainability reports: An overview of trends among corporate leaders
}

\author{
Konstantinos Evangelinos $^{1}$, Stefanos Fotiadis ${ }^{2}$, Antonis Skouloudis ${ }^{1,3 *}$, \\ Nadeem Khan ${ }^{3}$, Foteini Konstantakopoulou ${ }^{4}$, Ioannis Nikolaou ${ }^{5} \&$ Shaun Lundy $^{6}$ \\ ${ }^{1}$ Centre for Environmental Policy and Strategic Environmental Management \\ (EEPPD), Department of Environment, University of the Aegean, Greece \\ ${ }^{2}$ School of Economics, Business Administration \& Legal Studies, \\ International Hellenic University, Greece \\ ${ }^{3}$ Marketing and Reputation, Henley Business School, University of Reading, \\ Greenlands, Henley-on-Thames, United Kingdom \\ ${ }^{4}$ School of Science and Technology, Hellenic Open University, Patras, Greece, \\ ${ }^{5}$ Business and Environmental Technology Economics Lab (BETECO) \\ Democritus University of Thrace, Greece \\ ${ }^{6}$ Sustainable Built Environment Research Group (SBERG), \\ University of Greenwich, United Kingdom
}

(*) corresponding author: a.skouloudis@ @enley.ac.uk

\begin{abstract}
The purpose of this study is to assess the comprehensiveness of voluntary occupational health and safety (OHS) disclosures of large business entities. We devise a composite disclosure index relying on well-established performance indicators and focus on the information found in the sustainability reports of corporations pertaining to the oil and gas, chemical, airline and construction industries, in an attempt to shed light on the current status and emerging trends of OHS reporting from a diverse group of business entities. Findings indicate that companies tend to place emphasis on their overall management approach to OHS but fall short in reporting quantitative and qualitative information beyond 'conventional' metrics f occupational injury rates. OHS issues within the supply chain and relevant monitoring systems-mechanisms in place are issues underreported, while OHS training programs is an aspect inadequately analyzed in quantitative terms, being the least reported indicator in the sample reports. In contrast, companies from all four industries do seek assurance for
\end{abstract}


the OHS information they report and place emphasis on the externally-developed management standards/initiatives they subscribe to, support or have adopted.

Keywords: Sustainability reporting; occupational health and safety; voluntary disclosure; corporate responsibility; sustainable development.

\section{Introduction}

Nowadays the majority of large corporations publicly disclose their efforts in pursuit of sustainability through a single document: the sustainability report. Such reports have been identified as the new corporate 'business card'; a potentially valuable instrument for informing external and internal stakeholders of the firm on long-range planning and performance pertaining to critical economic, environmental and social (i.e. triple-bottom-line) aspects of the firm's operation (Kolk, 2010; Asif et al., 2013; Miralles-Quiros et al., 2017). This report can provide a meaningful outline of progress and evidence over target-setting beyond the financial domain, reduce information asymmetry, solidify organizational reputation and legitimacy while adding transparency in business activities (Elijido-Ten et al., 2010; Romolini et al., 2014; Martínez-Ferrero et al., 2016). Such reporting channels are primarily of voluntary nature across the world with only recently regional policy developments towards mandatory reporting requirements to have been intensified (see European Parliament, 2014).

Responding to UN's SDG3 ('ensure healthy lives and promote well-being for all'), occupational health and safety (OHS) reflects a core parameter of the corporate sustainability strategy and agenda for action as employees represent a primary internal stakeholder group for any corporation (Welford et al., 2008; Ketola, 2010). OHS is generally defined as a multidimensional construct concerned with the anticipation, 
recognition, evaluation and control of hazards arising in or from the workplace that could impair the health and well-being of workers, taking also into account possible impacts on the surrounding communities and the environment (Alli, 2008). It is a continuously evolving field shaped by socioeconomic, political and technological changes: competitive industry pressures, globalization and liberalization of world trade, demographic fluctuations and population movements, disruptive (technological) innovations, developments in transport and communication, regulatory changes, shifting employment patterns, transitions in the size as well as the structure and life cycle of enterprises (Alli, 2008). In this context, reporting on OHS issues reflects a critical point of corporate sustainability disclosure against a turbulent environment that generates new forms of employment hazards, exposures, risks and opportunities (Rikhardsson, 2004; Sarkis et al., 2010; Celma et al., 2014).

OHS accounting and reporting pertains to the collection, processing and disclosure of related information with the aim of facilitating organizational leadership, managerial effectiveness and empowering stakeholder decision-making (Rikhardsson, 2004). Several studies have examined OHS disclosure in the context of broader corporate nonfinancial reporting mechanisms (e.g. Campbell and Rahman, 2010; Holcomb et al., 2007; Li et al., 2011; Toppinen et al., 2011). Research findings suggest that OHS information provision can yield tangible benefits in bringing internal improvements of the working environment (Jain et al., 2011; Williams and Adams, 2013), attracting of new, talented, workforce (Earle, 2003), increasing customer loyalty (Dixon et al., 2016; Neumann et al., 2014), along with reputational and legitimacy gains (Makela, 2013). Nevertheless, OHS has received limited attention in sustainability reporting research despite the fact that low OHS conditions influence employees' well-being (Takala et al., 2014) and may incur striking socioeconomic costs (Tompa et al., 2008; WHO, 2010; Rose et al., 2013). 
Researchers denote that the frequency of information provision on such aspects of employment conditions is high (Islam and Deegan, 2008; Sotorrio and Sanchez, 2010), yet, the comprehensiveness of such disclosures is still moderate and leaves much to be desired (Walker and Parent, 2010; Jones, 2011). Available evidence reveals a lack of consistency and comprehensiveness across companies in terms of discretionary OHS data disclosure (Brown and Butcher, 2004; Bouten et al., 2011; Koskela, 2013; Searcy et al, 2016). O’Neill et al. (2015) relatively indicate the critical importance of severity metrics in disclosing lost time injuries to ensure meaningful social accountability and avoid incomplete or potentially misleading information provision. Cahaya et al. (2017) report that a mere $30 \%$ of publicly listed companies in Indonesia provide OHS disclosures in their annual reports and note an industry-effect on the level of information reported. In this respect, O'Neill et al. (2016) find that firms in hazardous industries provide more OHS performance information than those pertaining to less hazardous sectors, with a strong reliance on highly aggregated frequency rates and efforts to reduce the visibility of high-consequence safety system failures over time. Likewise, focusing on the annual reports of airline companies, Vourvachis et al (2016) point out increases in OHS disclosure after major airline accidents (as a response to potential legitimacy threats) and stress the need for greater transparency and comparability across reports. Such evidence casts doubt on the ability to empower stakeholders' decision-making and allow meaningful comparisons over time and across business entities, exacerbating issues pertaining to information asymmetry (Fortanier et al., 2011; Young and Marais, 2013; Searcy et al., 2016).

With this in mind, and motivated by the scant attention OHS reporting has received in the corporate accountability literature, this study assesses the quality and comprehensiveness of OHS disclosures in sustainability reports published by large corporations of selected industries: the oil and gas, construction, airline and chemical 
sectors. To achieve this, an OHS disclosure index is developed relying on the related performance measures suggested by the Global Reporting Initiative (GRI) G4 guidelines. Our key contribution to the literature pertains to the quantitative examination of a critical, yet understudied, aspect of discretionary corporate reporting with the aim of identifying trends and discrepancies that provide fruitful ground towards the refinement and readjustment of current voluntary OHS reporting mechanisms and performance disclosures (with managerial and policy implications).

The rest of the paper is structured as follows. In the next section, the material and methods are described. In the third section, the findings of the study are presented. The paper ends with a discussion and concluding remarks pointing out managerial and policy implications as well as future research perspectives.

\section{Material and methods}

Our sample consists of ten of the largest corporations (based on revenue) from each one of the following industries: oil and gas, construction, aviation and chemicals. These 40 corporations were drawn from the Forbes World's Biggest Companies List 2014 (Tables 1 and 2). The selection of the particular industrial sectors was based on the diverse issues pertaining to OHS these business activities face as well as the lack of international industry-level evidence on trends of voluntary OHS-specific corporate disclosure. We focused on the stand-alone CSR reports published by these firms in 2015 (i.e. referring to performance achievements of the previous year).

\section{(Insert Tables 1 \& 2 around here)}

In order to assess the comprehensiveness of reported information a composite disclosure index was devised for each corporation $j$, in line with the structure and 
rationale of previous rating schemes suggested in the literature (Skouloudis et al., 2013; Evangelinos et al., 2016; Halkos and Skouloudis, 2016). This measure was derived from specific disclosure requirements of the Global Reporting Initiative G4 guidelines for sustainability reports that refer to firm-specific OHS management and performance reporting themes. These items, presented in Table 3, were rated on 5point scale and the generic scoring scheme applied to the assessment is outlined in Table 4. Based on the defined $t_{i}$ OHS topics-criteria $(i=1,2, \ldots, 10)$ the proposed composite OHS disclosure index for corporation $j$ was constructed as follows:

$$
\left.\operatorname{OHSD}_{(j)}=\sum_{i=1}^{10} I t_{i j}\right\} \quad(I=0,1,2,3,4)
$$

where $I_{\left\{t_{i j}\right\}}$ is an indicator variable for measuring the $i$ OHS topics-criteria on company $j$, that equals to zero for non-disclosure, 1 if the organization $j$ discloses vague/sententious information on the $i$ th topic, 2 if it provides relevant but inadequate information/data, 3 if the coverage is comprehensive and 4 if it is fully in line with GRI's implementation manual. This results to an index of a maximum score of 40 points. These disclosure scores - presented in the following section - are expressed in percentages. The assessment was performed between July 2016 and October 2016, independently by four researchers with previous experience with relevant coding schemes and content analysis assessments. While there was a negligible number of scoring criteria where discrepancies in evaluation scores was identified, these were reexamined by the coders and modified accordingly in order to address issues of intercoding errors and any needs for further emphasis on such reliability issues. 


\section{Findings}

Results are presented in terms of individual GRI item (Figure 1) as well as for the overall score assigned to each report (Figure 2) with an attempt to summarize trends both among sectors and GRI indicators.

Taking into account industry trends (Figure 1), we find that reports from chemical companies reveal a high level of sensitivity to OHS issues. Overall, they provide a satisfactory level of disclosures detailing their approach to OHS management (G4DMA) as well as the relevant standards and initiatives they subscribe to (G4-15), apart from the quantitative indicator pertaining to the annual amount of OHS training hours per employee (LA9) which is not covered in none of the assessed reports. Construction companies retain a similar approach to OHS reporting, providing slightly more information on OHS training programs (LA9) but falling short in terms of third-party assurance of disclosed OHS performance data (G4-33). Oil and gas companies tend to disclose information on all the components comprising the OHSD index. Major shortcomings are identified in the disclosure of quantitative data on OHS training hours (LA9) and the specification of (formal) agreements between the company and trade unions with regards to OHS issues (LA8). Nevertheless, these corporations present comprehensively in their reports the OHS-specific initiatives and standards they have adopted (G4-15) while they actively endorse the verification of performance-related OHS disclosures included in their reports (G4-33). Reports by airline companies suffer from major gaps in OHS reporting and the non-disclosure of critical OHS information such as the existence of OHS clauses in the formal agreements with trade unions (LA8) and the screening of suppliers under OHS performance criteria (LA14). Yet, they do provide the overall management approach of the company to OHS challenges (G4-DMA) while six of them do sought for external verification of the reported OHS information (G4-33). 
Sample firms from all four assessed industries identify in their reports the critical importance of OHS-related practices and disclose with no significant discrepancies their management approach to OHS (G4-DMA) pointing out policies, plans and programs in place to promote a safe and healthy work environment (Figures 2). Likewise, $98 \%$ of the assessed corporations elaborate on the externally-developed OHS-related charters, principles, standards or other initiatives to which they subscribe to, implement or actively endorse (G4-15). However, all sample firms fail to report on joint management-worker health and safety committees which can help monitor and advise on OHS programs (LA5). In this respect, the percentage of total workforce represented in such formal committees is not disclosed in the assessed reports.

In contrast, quantitative OHS indicators (i.e. rates of injury by type, occupational diseases, lost days, absenteeism, number of work-related fatalities, etc.) are reported by $95 \%$ of the sample (LA6), often utilizing graphs and tables to communicate performance achievements. Yet, airline companies tend to disclose less OHS performance data, focusing primarily on injury rates and/or the number of fatal accidents. Construction and chemical industries disclosure comparatively more comprehensive information on disease-specific incidents or risks for workers which are linked to their occupation, followed by the oil and gas companies (LA7). Airline companies exhibit a not so uniform approach to this OHS aspect, with some firms to discuss the topic in detail and/or in a clear manner while others to elaborate on such risks superficially. OHS topics covered and included in formal agreements with trade unions of the reporting entity (LA8) is an issue mostly overlooked by most corporations of our sample as only $15 \%$ of them present sufficient information on the topic, with the rest to either provide vague and brief disclosures or choose not to raise any points on the existence of such arrangements with their trade unions. Likewise, information about employee training on OHS issues (LA9) is scarce, as only three 
firms (pertaining to the oil and gas and the construction sectors) specifying absolute or relative figures related to hours of OHS training per gender and/or by employee category.

Chemical and oil and gas companies tend to provide comparatively more disclosures on screening criteria they have in place for their new and existing suppliers, partners and or contractors in terms of applied OHS management practices (LA14), while only three airline companies disclose relevant information in terms of generic statements and vague remarks referring to supply chain management. Similarly, identification of actual and potential negative impacts for OHS practices in the supply chains (LA15) is an issue addressed in very few of the CSR reports of airline firms with the other three sectors to provide a rather uniform approach in disclosing relevant information. Finally, third-party verification of OHS performance data and related organizational assertions (G4-33) is endorsed by all the oil and gas corporations, followed by the majority of the airline as well as the chemical industries.

Figure 3 presents the average OHSD scores broken down in terms of region and business sector. Higher levels of OHSD are generally evident for the chemical enterprises in comparison to the other sectors, and for the companies located in Europe, with only exception being the Asian companies operating in the oil and gas sector.

In order to examine potential associations between the OHSD index and the descriptive variables of international presence, revenue and the number of employees of companies, Figures 4-6, illustrate scatter plots between the latter variables with respect to the different types of selected industries. Visual inspection of the three plots indicates no association between OHSD and the companies' international presence (Figure 4). Partial associations between OHSD and revenue are observed, with the 
exception of the firms operating in the oil \& gas sector (see Figure 5). Finally, the scatter plot in Figure 6 indicates a positive association between OHSD and the number of employees, described with a rather linear trend for the construction, airline and chemical firms, and a non-linear association for the oil and gas companies. The corresponding scatterplots with respect to the various regions (derived from the firm's country of origin) of the companies are presented in Figures A1-A3 in the Appendix, generally revealing similar results.

\section{Discussion}

Reflecting on the overall findings, our assessment is in accord with the recent wave of studies pertaining to organizational accountability on work environment issues (see Jain et al., 2011; Williams and Adams, 2013; Koskela, 2014; Searcy et al., 2016) and reveals variations in the comprehensiveness of corporate OHS disclosures both between and within sectors. Such differentiated levels of information provision are also identified among the ten components of the proposed disclosure index and stress problems in cross-comparing performance and in the appraisal of OHS practices by stakeholders (i.e. information asymmetry). Companies tend to emphasize on their overall management approach to OHS but fall short in reporting quantitative data (along with complimentary information) beyond occupational injury and absenteeism rates. OHS issues within the supply chain and relevant monitoring systemsmechanisms in place are also issues underreported. Similarly, relevant workforce training programs is an aspect mostly overlooked and not adequately analyzed in quantitative terms, being the least report indicator in the sample reports. Yet, companies from all four case industries seek for assurance of the disclosed OHS information which should be considered in conjunction with the emphasis they attach to externally-developed management standards and initiatives (e.g. OHSAS 18001, 
Global Compact principles). This is mostly evident among the oil and gas and chemical corporations while a similar emphasis on occupational disease-related risks is observed in the reports of the latter as well as those of construction firms.

While OHS has been pinpointed as a material issue in these industries in their respective reports there seems to be a mismatch of importance attached to reported OHS performance as it tends to be 'reduced' to the disclosure of the management systems in place and the number of occupational accidents/absenteeism rates. It is evident from the assessed reports that these companies consider OHS as a priority issue; sophisticated programs and projects are implemented by most of them with the aim of driving improvements in the OHS terrain. Yet, the reported information do not fully signal the importance attached in this critical area of the workplace environment. The respective disclosures do not correspond to this level of importance attached as reporting entities tend to rely on data and information available from their legal requirements as well as the OHS standards they apply and tend to avert from disclosing additional or more detailed analysis in OHS terms. In this respect, targetsetting in relation to health and safety in the workplace is an aspect covered fragmentarily and related SMART ${ }^{1}$ targets are not frequently reported in order to communicate progress and long-range planning in this area. Deegan et al. (2002) relatively indicate that "where there is limited concern, there will be limited disclosures" (p. 335) and OHS reporting of assessed firms indeed leaves much to be desired as gaps and shortcoming confirm the findings already identified in other studies and sectors (Branco and Rodrigues, 2008; Khan et al., 2009; Hinson et al., 2010).

The study encapsulates managerial implications as more comprehensive OHS reporting could contribute to better monitoring of OHS risks and opportunities as well 
as to meaningful stakeholder communication. Such managerial implications highlight the need to design engagement programs for meaningful employee input in this regard, as long as such accountability schemes are developed around the workforce's demands or expectations and are built around fruitful employee-consultation processes (Williams and Adams, 2013). In addition, better OHS reporting could support strategic marketing advantages given the growing number of consumers willing to support and choose products/services from companies providing credible information on their working conditions (e.g. Neumann et al., 2014). Such competitive advantages (Porter and Kramer, 2006) could act as motivators within the firm to enhance and maintain a higher level of accountability on employee working conditions, occupational hazards and the endorsement of a healthy and safe working environment. By linking more transparent reporting around the OHS agenda with brand image and organizational reputation (Hunter and Van Wassenhove, 2011), managers may leverage the differentiation strategy of the firm, shape new or boost existing marketing advantages while increasing customer loyalty (Randall, 2005; Neumann et al., 2014). Hence, OHS reporting may encapsulate an untapped reservoir of added value for the firm and attending the issue in a manner similar to promoting 'green' products or environmentally benign behavior can contribute to the sustainability (reporting) agenda, primarily in terms of employee-management and consumer-company dialogue and fruitful engagement (Mason and Simmons 2011; Zink and Fischer 2013; Bolis et al., 2014). Nevertheless, recent evidence suggest that consumers do not receive adequate information on the working conditions of firms (Dixon et al., 2016), a problem which should be alarming to top management executives in terms of underlying inefficiencies and the potential skepticism or mistrust around OHS performance mere 'aspirational talks' may spawn (Behm and Schneller, 2011; Boiral, 2013; Christensen et al., 2013). 


\section{Concluding remarks}

While our results are far from conclusive on corporate OHS disclosure and do not allow generalizations, they indicate that further steps towards less inconsistent and more comprehensive OHS reporting are required. Our assessment did not examine on the actual performance of firms and focused only on the disclosures included in the sustainability report. Hence, companies that operate robust systems of OHS management but choose to publish little information in their report will score low in the OHSD index. Likewise, firms that may cover superficially all OHSD components may receive a similar score with peers that focus on a limited set of items/indicators but address them in detail.

As Western corporations scored higher than their Middle Eastern and Asian peers, researchers could explore institutional determinants of OHS disclosure taking into account developments such as the recent EU Directives for nonfinancial reporting of large undertakings and groups. Future research could also shed light on regional and/or industry-specific factors influencing OHS reporting. This could be achieved either through quantitative analysis on larger samples, including other communication channels (beyond the sustainability report) and broader work environment themes, or by employing action research assessments on how OHS reporting is devised, how material OHS aspects and indicators are selected for disclosure and how external guidelines (such as the GRI ones) are adopted and incorporated in the process. It is research endeavors such as the above which could add to a better understanding of how OHS reporting contributes to long term win-win-win conditions for organizations, their workforce and society at large. 


\section{References}

Alli BO. 2008. Fundamental principles of occupational health and safety. International Labour Office: Geneva.

Asif M, Searcy C, Santos PD, Kensah D. 2013. A review of Dutch corporate sustainable development reports. Corporate Social Responsibility and Environmental Management 20(6): 321-339.

Behm M, Schneller A. 2011. Externally reported occupational health \& safety data among U.S. manufacturing firms. Journal of Safety, Health \& Environmental Research 7(1): 10-15.

Boiral O. 2013. Sustainability reports as simulacra? A counter-account of A and A+ GRI reports. Accounting, Auditing \& Accountability Journal 26(7): 1036-1071.

Bolis I, Brunoro CM, Sznelwar LI. 2014. Mapping the relationships between work and sustainability and the opportunities for ergonomic action. Applied Ergonomics 45(4): 1225-1239.

Bouten L, Everaert P, Van Liedekerke L, De Moor L, Christiaens J. 2011. Corporate social responsibility reporting: a comprehensive picture? Accounting Forum 35(3): 187-204.

Branco MC, Rodrigues LL. 2008. Social responsibility disclosure: a study of proxies for the public visibility of Portuguese banks. The British Accounting Review 40(2): 161-181.

Brown J, Butcher F. 2005. Reporting on occupational health and safety in annual reports: a look at disclosure practices in New Zealand. New Zealand Journal of Employment Relations 30(1): 335-345.

Cahaya FR, Porter S, Tower G, Brown A. 2017. Coercive pressures on occupational health and safety disclosures. Journal of Accounting in Emerging Economies 7(3): 318-336.

Campbell D, Rahman MRA. 2010. A longitudinal examination of intellectual capital reporting in Marks \& Spencer annual reports, 1978-2008. The British Accounting Review 42(1): 56-70.

Celma D, Martínez-Garcia E, Coenders G. 2014. Corporate social responsibility in human resource management: an analysis of common practices and their determinants in Spain. Corporate Social Responsibility and Environmental Management 21(2): 82-99. 
Christensen LT, Morsing M, Thyssen O. 2013. CSR as aspirational talk. Organization 20(3): 372-393.

Deegan C, Rankin M, Tobin J. 2002. An examination of the corporate social and environmental disclosures of BHP from 1983-1997: A test of legitimacy theory. Accounting, Auditing \& Accountability Journal 15(3): 312-343.

Dixon SM, Nordvall AC, Cukier W, Neumann WP. 2016. Young consumers' considerations of healthy working conditions in purchasing decisions: A qualitative examination. Ergonomics, doi:10.1080/00140139.2016.1193634.

Earle HA. 2003. Building a workplace of choice: Using the work environment to attract and retain top talent. Journal of Facilities Management 2(3): 244-257.

Elijido-Ten E, Kloot L, Clarkson P. 2010. Extending the application ofstakeholder influence strategies to environmental disclosures: An exploratory study from a developing country. Accounting, Auditing \& Accountability Journal 23(8): 10321059.

European Parliament, Council of the European Union. 2014. Directive 2014/95/EU of the European Parliament and the Council of 22 October 2014 amending Directive 2013/34/EU as regards disclosure of non-financial and diversity information by certain large undertakings and groups. European Parliament: Brussels.

Evangelinos K., Skouloudis A, Jones N, Isaac D, Sfakianaki E. 2016. Exploring the status of corporate social responsibility disclosure in the UK building and construction industry. International Journal of Global Environmental Issues 15(4): 377-399.

Fortanier F, Kolk A, Pinkse J. 2011. Harmonization in CSR reporting. Management International Review 51(5): 665-696.

Halkos G, Skouloudis A. 2016. Exploring the current status and key determinants of corporate disclosure on climate change: Evidence from the Greek business sector. Environmental Science and Policy 56(February): 22-31.

Hinson R, Boateng R, Madichie N, 2010. Corporate social responsibility activity reportage on bank websites in Ghana. International Journal of Bank Marketing 28(7): 498-518.

Holcomb JL, Upchurch RS, Okumus F. 2007. Corporate social responsibility: What are top hotel companies reporting? International Journal of Contemporary Hospitality Management 19(6): 461-475. 
Hunter ML, Van Wassenhove LN. 2011. Hayleys PLC: Corporate responsibility as stakeholder relations. Journal of Management Development 30(10): 968-984.

Islam MA, Deegan C. 2008. Motivations for an organisation within a developing country to report social responsibility information. Accounting, Auditing \& Accountability Journal 21(6): 850-874.

Jain A, Leka S, Zwetsloot G. 2011. Corporate social responsibility and psychosocial risk management in Europe. Journal of Business Ethics 101(4): 619-633.

Jones MJ. 2011. The nature, use and impression management of graphs in social and environmental accounting. Accounting Forum 35(2): 75-89.

Ketola T. 2010. Five leaps to corporate sustainability through a corporate responsibility portfolio matrix. Corporate Social Responsibility and Environmental Management 17(6): 320-336.

Khan MH, Halabi AK, Samy M. 2009. Corporate social responsibility (CSR) reporting: a study of selected banking companies in Bangladesh. Social Responsibility Journal 5(3): 344-357.

Kolk A. 2010. Trajectories of sustainability reporting by MNCs. Journal of World Business 45(4): 367-374.

Koskela M. 2014. Occupational health and safety in corporate social responsibility reports. Safety Science 68: 294-308.

Li N, Toppinen A, Tuppura A, Puumalainen K, Hujala M, 2011. Determinants of sustainability disclosure in the global forest industry. Electronic Journal of Business Ethics and Organizational Studies 16(1): 33-40.

Mäkelä H. 2013. On the ideological role of employee reporting. Critical Perspectives on Accounting 24(4-5): 360-378.

Martínez-Ferrero J, Ruiz-Cano D, García-Sánchez IM. 2016. The causal link between sustainable disclosure and information asymmetry: The moderating role of the stakeholder protection context. Corporate Social Responsibility and Environmental Management 23(5): 319-332.

Mason C, Simmons J. 2011. Forward looking or looking unaffordable? Utilising academic perspectives on corporate social responsibility to assess the factors influencing its adoption by business. Business Ethics: A European Review 20(2): 159-176. 
Miralles-Quiros MM, Miralles-Quiros JL, Irene Guia Arraiano IG. 2017. Are firms that contribute to sustainable development valued by investors? Corporate Social Responsibility and Environmental Management 24: 71-84.

Neumann WP, Dixon SM, Nordvall AC. 2014. Consumer demand as a driver of improved working conditions: the 'Ergo-Brand' proposition. Ergonomics 57(8): 1113-1126.

O’Neill S, Flanagan J, Clarke K. 2016. Safewash! Risk attenuation and the (Mis) reporting of corporate safety performance to investors. Safety Science 83: 114-130.

O'Neill S, McDonald G, Deegan CM. 2015. Lost in translation: Institutionalised logic and the problematisation of accounting for injury. Accounting, Auditing \& Accountability Journal 28(2): 180-209.

Porter ME, Kramer MR, 2006. Strategy and Society: The link between competitive advantage and corporate social responsibility. Harvard Business Review 84(12): 7892.

Randall DC. 2005. An exploration of opportunities for the growth of the Fair Trade market: Three cases of craft organisations. Journal of Business Ethics 56(1): 55-67.

Rikhardsson PM. 2004. Accounting for the cost of occupational accidents. Corporate Social Responsibility and Environmental Management 11(2): 63-70.

Romolini A, Fissi S, Gori E. 2014. Scoring CSR reporting in listed companiesEvidence from Italian best practices. Corporate Social Responsibility and Environmental Management 21(2): 65-81.

Rose L, Orrenius UE, Neumann WP. 2013. Work environment and the bottom line: survey of tools relating work environment to business results. Human Factors and Ergonomics in Manufacturing \& Service Industries 23(5): 368-381.

Sarkis J, Helms MM, Hervani AA. 2010. Reverse logistics and social sustainability. Corporate Social Responsibility and Environmental Management 17(6): 337-354.

Searcy C, Dixon SM, Neumann WP. 2016. The use of work environment performance indicators in corporate social responsibility reporting. Journal of Cleaner Production 112: 2907-2921.

Sotorrio LL, Sanchez JLF. 2010. Corporate social reporting for different audiences: the case of multinational corporations in Spain. Corporate Social Responsibility and Environmental Management 17(5): 272-283.

Takala J, Hamalainen P, Saarela KL, Yun LY, Manickam K, Jin TW, Heng P, Tjong C, Kheng LG, Lim S, Lin GS. 2014. Global estimates of the burden of injury and 
illness at work in 2012. Journal of Occupational and Environmental Hygiene 11(5): 326-337.

Tompa E, Culyer AJ, Dolinschi R. 2008. Economic evaluation of interventions for occupational health and safety: Developing good practice. Oxford University Press: Oxford.

Toppinen A, Li N, Tuppura A, Xiong Y. 2011. Corporate responsibility and strategic groups in the forest-based industry: Exploratory analysis based on the Global Reporting Initiative (GRI) framework. Corporate Social Responsibility and Environmental Management 19(4): 191-205.

Vourvachis P, Woodward T, Woodward DG, Patten DM. 2016. CSR disclosure in response to major airline accidents: a legitimacy-based exploration. Sustainability Accounting, Management and Policy Journal 7(1): 26-43.

Walker M, Parent MM. 2010. Towards an integrated framework of corporate social responsibility, responsiveness, and citizenship in sport. Sport Management Review 13: 198-213.

Welford R, Chan C, Man M. 2008. Priorities for corporate social responsibility: a survey of businesses and their stakeholders. Corporate Social Responsibility and Environmental Management 15(1): 52-62.

Williams SJ, Adams CA. 2013. Moral accounting? Employee disclosures from a stakeholder accountability perspective. Accounting, Auditing \& Accountability Journal 26(3): 449-495.

World Health Organization (WHO). 2010. Healthy workplace framework and model: Background and supporting literature and practices. World Health Organization Press: Geneva.

Young S, Marais M. 2013. Gaining legitimacy in large Australian listed companies: exploring the role of corporate reporting regarding employees. Labour \& Industry: a journal of the social and economic relations of work 23(1): 13-33.

Zink KJ, Fischer K. 2013. Do we need sustainability as a new approach in human factors and ergonomics? Ergonomics 56(3): 348-356. 
Table 1. Sample firms - descriptive information

\begin{tabular}{|c|c|c|c|c|c|}
\hline Sector & Companies & $\begin{array}{c}\text { Country of } \\
\text { Origin }\end{array}$ & Revenue (2014) & Employees & $\begin{array}{c}\text { International } \\
\text { presence }^{2}\end{array}$ \\
\hline \multirow{10}{*}{ Oil and Gas } & Sinopec & China & $455.06 \$$ bn & About 358,600 & 70 \\
\hline & CNPC & China & $432 \$$ bn & about 534,700 & 37 \\
\hline & Shell & Anglo-Dutch & 422 \$ bn & 94,000 & Over 70 \\
\hline & ExxonMobil & USA & 394 \$ bn & 83,700 & Over 50 \\
\hline & Saudi Aramco & Saudi Arabia & 378 \$bn & 61,000 & 6 \\
\hline & $\mathrm{BP}$ & Iran & $358.7 \$$ bn & 84,500 & $\sim 80$ \\
\hline & Total & France & $260 \$$ bn & About 100,310 & Over 130 \\
\hline & Kuwait Pet.Cor. & Kuwait & $252 \$ b n$ & About 18,570 & 9 \\
\hline & Chevron Cor. & USA & 192 \$ bn & About 64,700 & 30 \\
\hline & Lukoil & Russia & $144 \$$ bn & Over 110,000 & 7 \\
\hline \multirow{10}{*}{$\begin{array}{l}\text { Construction } \\
\text { services }\end{array}$} & Vinci & France & $38.7 \$$ bn & 68,000 & $\sim 100$ \\
\hline & Bechtel & USA & $37.2 \$$ bn & 58,000 & 160 \\
\hline & ACS Group & Spain & $35.504 \$$ bn & 210,345 & Over 40 \\
\hline & Hochtief & Germany & $22.1 \$ b n$ & About 68,430 & Over 20 \\
\hline & Bouygues Constr. & France & $11.726 \$$ bn & Over 130,000 & 80 \\
\hline & Kiewit & USA & 10.38 \$ bn & 25,700 & 3 \\
\hline & Royal Bam Group & Netherlands & $9.97 \$$ bn & About 26,100 & 13 \\
\hline & Balfour Beatty & UK & $8.8 \$$ bn & About 40,000 & Over 80 \\
\hline & Skanska & Sweden & $7.3 \$ \mathrm{bn}$ & About 58,000 & 10 \\
\hline & Laing O’Rourke & UK & $4.41 \$ \mathrm{bn}$ & About 11,300 & 9 \\
\hline \multirow{10}{*}{ Airlines } & America Airl. Gr. & USA & $42.65 \$$ bn & 113,300 & 150 \\
\hline & Delta & USA & $40.36 \$$ bn & 80,000 & 57 \\
\hline & Unit.Contin.Hold. & USA & $38.90 \$$ bn & 84,000 & 58 \\
\hline & Lufthansa Group & Germany & $31.9 \$$ bn & About 118,780 & 100 \\
\hline & AirFrance-KLM & $\begin{array}{c}\text { France \& } \\
\text { Holland }\end{array}$ & $26.5 \$ b n$ & 96,000 & 115 \\
\hline & Emirates Group & UAE & $26.24 \$$ bn & About 84,150 & 81 \\
\hline & IAG & UK \&Spain & $21.46 \$$ bn & About 59,490 & Over 80 \\
\hline & Southwest & USA & $18.61 \$$ bn & Over 49,000 & 7 \\
\hline & China Southern & China & $16.99 \$$ bn & 90,000 & 40 \\
\hline & China Eastern & China & $14.69 \$$ bn & About 68,880 & 26 \\
\hline \multirow{10}{*}{ Chemicals } & BASF & Germany & $74.326 \$$ bn & About 113,300 & Over 90 \\
\hline & Dow & USA & $58.167 \$$ bn & 53,000 & 35 \\
\hline & LyondellBasell & USA & $45.61 \$ \mathrm{bn}$ & 13,100 & 19 \\
\hline & Sabic & Saudi Arabia & $50.36 \$$ bn & 40,000 & Over 50 \\
\hline & Bayer & Germany & $42.239 \$$ bn & 118,000 & 75 \\
\hline & Dupont & Mexico & 35.7 \$ bn & 63,000 & Over 90 \\
\hline & Linde & Germany & $17.047 \$$ bn & About 65,600 & Over 100 \\
\hline & Henkel & Germany & 16.428 \$ bn & 49,750 & Over 75 \\
\hline & PPG & USA & $15.360 \$$ bn & 44,400 & $\sim 70$ \\
\hline & AirLiquide & France & $15.358 \$$ bn & 50,300 & Over 80 \\
\hline
\end{tabular}

Table 2. Information relative to CSR and OHS issues

${ }^{2}$ Number of countries where the corporation operates. 


\begin{tabular}{|c|c|c|c|c|c|}
\hline Companies & $\begin{array}{l}\text { Pages of CSR } \\
\text { Report in } 2014\end{array}$ & $\begin{array}{c}\text { Pages on OHS } \\
\text { in CSR } 2014\end{array}$ & $\begin{array}{c}\text { OHSAS } \\
\text { 18001:2007 }\end{array}$ & $\begin{array}{c}\text { SAI } \\
\text { SA8000:2008 }\end{array}$ & $\begin{array}{c}\text { PN-ISO } \\
\text { 26000:2012 }\end{array}$ \\
\hline Sinopec & 98 & 7 & - & - & - \\
\hline CNPC & 56 & 2.5 & PI & - & Included \\
\hline Shell & 57 & 2 & - & - & - \\
\hline ExxonMobil & 75 & 12 & Included & - & - \\
\hline Saudi Aramco & 82 & 10 & PI & & \\
\hline $\mathrm{BP}$ & 52 & 8 & PI & PI & PI \\
\hline Total & 60 & 1 & PI & - & - \\
\hline Kuwait Pet.Cor. & online & online & - & - & - \\
\hline ChevronCor. & 26 & 3 & Included & - & - \\
\hline Lukoil & 126 & 5 & Included & - & - \\
\hline Vinci & Within Annual & online & Included & - & Included \\
\hline Bechtel & 37 & Limited & - & - & - \\
\hline ACS Group & 106 & 4 & PI & - & - \\
\hline Hochtief & Within Annual & 3 & PI & - & - \\
\hline Bouygues Constr. & 64 & 4 & PI & - & - \\
\hline Kiewit & online limited & $\begin{array}{l}\text { Extremely } \\
\text { Limited }\end{array}$ & - & - & - \\
\hline Royal Bam Group & 254 & 1 & Included & - & Included \\
\hline Balfour Beatty & 14 & 1 & Included & - & - \\
\hline Skanska & 36 & Limited & PI & - & - \\
\hline Laing O'Rourke & 77 & 0.5 & - & - & - \\
\hline America Airl. GR. & online & online & - & $\overline{-}$ & - \\
\hline Delta & 81 & 4 & - & - & - \\
\hline Unit.Contin.Hold. & online & online & - & - & - \\
\hline Lufthansa Group & 113 & 2 & Included & - & - \\
\hline AirFrance-KLM & 88 & 3 & Included & - & - \\
\hline Emirates Group & 52 & online & - & - & - \\
\hline Inter.Airl.Grroup & Within Annual & 1 & - & - & - \\
\hline Southwest & 170 & 2 & - & - & - \\
\hline China Southern & 72 & 2 & - & - & - \\
\hline China Eastern & 84 & 2 & - & & Included \\
\hline BASF & 232 & 4 & Included & - & - \\
\hline Dow & 177 & 6 & - & - & - \\
\hline LyondellBas. & online & online & - & - & - \\
\hline Sabic & 79 & 8 & - & - & - \\
\hline Bayer & 310 & 3 & Included & - & Included \\
\hline Dupont & 11 & 1 & PI & - & - \\
\hline Linde & 106 & 3 & PI & - & - \\
\hline Henkel & 48 & 2 & PI & Included & - \\
\hline PPG & online & online & - & - & - \\
\hline AirLiquide & 362 & 4 & PI & - & - \\
\hline
\end{tabular}

Notes to table 2: Extremely Limited: there are 1-4 lines or some scattered information associated with OHS issues; Limited: here are a few lines relative to OHS issues; Included: the specific standard/guidance is fully adopted by the company; PI: the specific standard/guidance is partially included from/adopted by the company; '-': there is no indication/reference to the specific standard. 
Table 3. The components comprising the proposed OHSD index

\begin{tabular}{|c|c|}
\hline GRI item & Description \\
\hline G4-DMA* & Disclosure of Management Approach on OHS \\
\hline G4-15* & $\begin{array}{l}\text { List externally developed OHS-related charters, principles, or other social } \\
\text { initiatives to which the organization subscribes or which it endorses }\end{array}$ \\
\hline G4-33* & $\begin{array}{l}\text { Assurance of OHS disclosures or third-party verification of OHS } \\
\text { Management System in place }\end{array}$ \\
\hline LA5 & $\begin{array}{l}\text { Percentage of total workforce represented in formal joint management- } \\
\text { worker health and safety committees that help monitor and advise on } \\
\text { occupational health and safety programs }\end{array}$ \\
\hline LA6 & $\begin{array}{l}\text { Rates of injury, occupational diseases, lost days, and absenteeism, and } \\
\text { number of work-related fatalities by region and by gender }\end{array}$ \\
\hline LA7 & Workers with incidence or high risk of diseases related to their occupation \\
\hline LA8 & Health and Safety topics covered in formal agreements with trade unions \\
\hline LA9 & $\begin{array}{l}\text { Average hours of OHS training per year per gender, and by employee } \\
\text { category }\end{array}$ \\
\hline LA14* & $\begin{array}{l}\text { Percentage of new suppliers (or partners, contractors) that were screened } \\
\text { using OHS practices criteria }\end{array}$ \\
\hline LA15* & $\begin{array}{l}\text { Significant actual and potential negative impacts for OHS practices in the } \\
\text { supply chains and actions taken }\end{array}$ \\
\hline
\end{tabular}

(*adapted by the authors to fit the purpose of the study).

Table 4: Basic rating qualification scale

\begin{tabular}{|c|l|}
\hline Points & \multicolumn{1}{|c|}{ Rating qualifications/requirements } \\
\hline 0 & $\begin{array}{l}\text { The report does not include any information relevant to the specific GRI } \\
\text { topic/indicator. No coverage. }\end{array}$ \\
\hline 1 & $\begin{array}{l}\text { The report provides generic or brief statements, without specific } \\
\text { information on the organisations approach to the topic/indicator. }\end{array}$ \\
\hline 2 & $\begin{array}{l}\text { The report includes valuable information on the topic/indicator but there are } \\
\text { still major gaps in coverage. The organisation identifies the assessed issue, } \\
\text { but fails to present it sufficiently. }\end{array}$ \\
\hline 3 & $\begin{array}{l}\text { The provided information is adequate and clear. It is evident that the } \\
\text { reporting organisation has developed the necessary systems and processes } \\
\text { for data collection on the assessed topic/indicator and attempts to present it } \\
\text { in a consistent manner. }\end{array}$ \\
\hline 4 & $\begin{array}{l}\text { Coverage of the specific issue can be characterised as "full" in the report. It } \\
\text { provides the organisation's policy, procedures/programs and relevant } \\
\text { monitoring results for addressing the issue. The organisation meets the GRI } \\
\text { OHS-specific requirements, allowing comparison with other organisations. }\end{array}$ \\
\hline
\end{tabular}


Figure 1: Results per GRI-G4 OHS-specific item/indicator (\%).
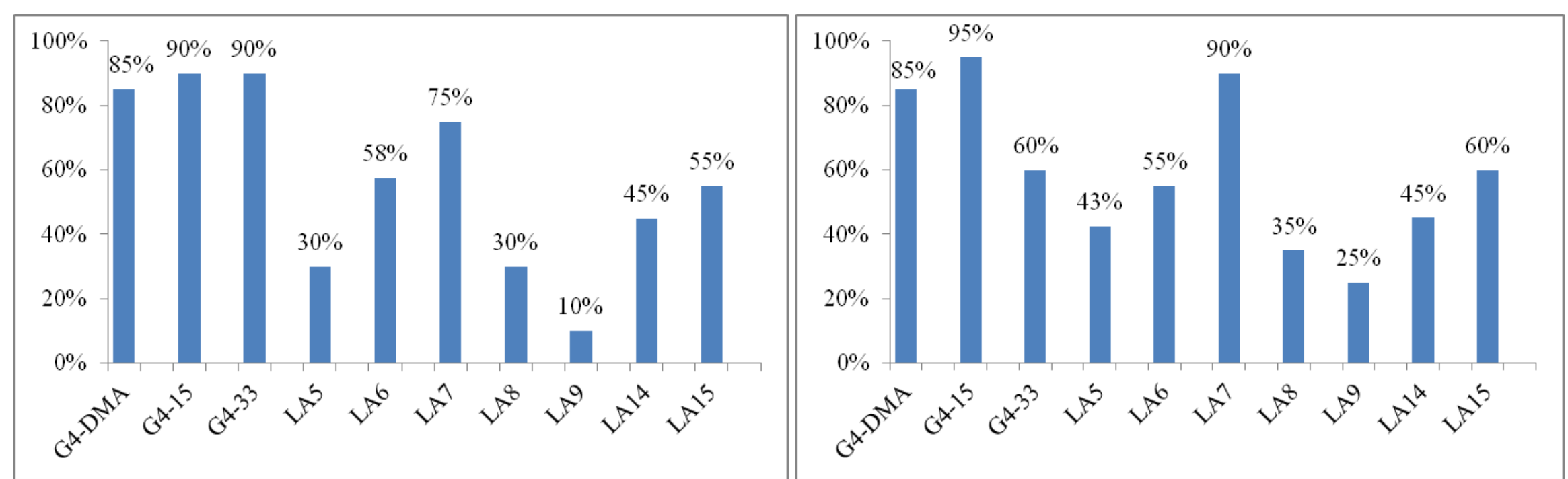

Oil and gas

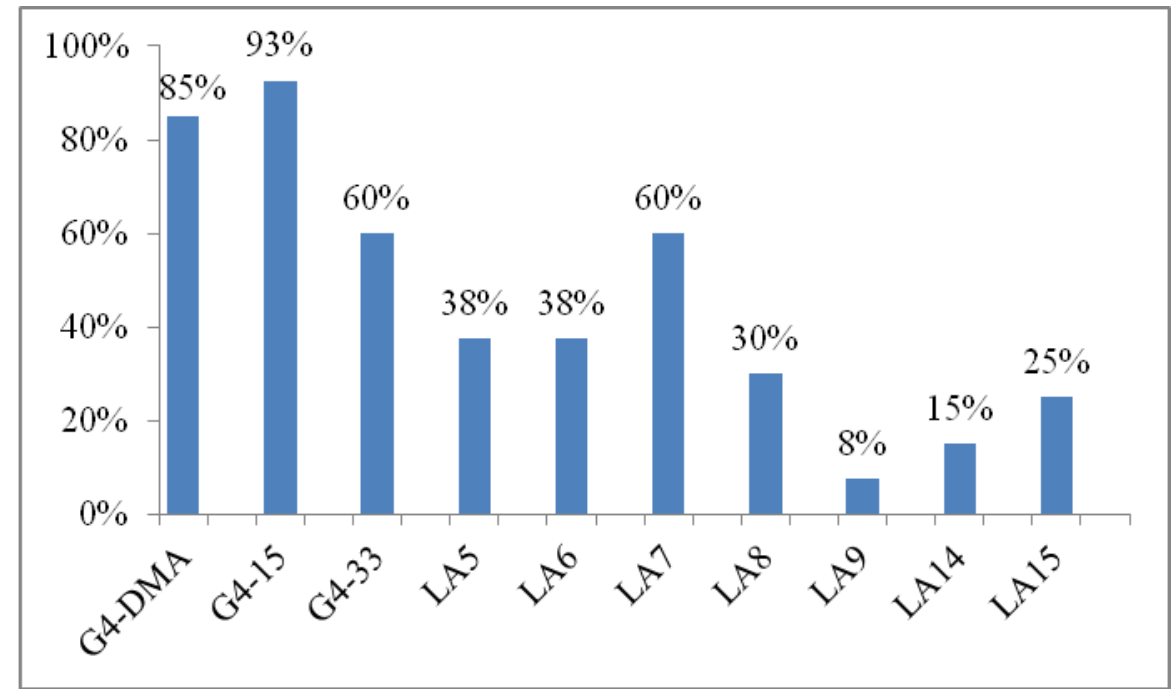

Construction

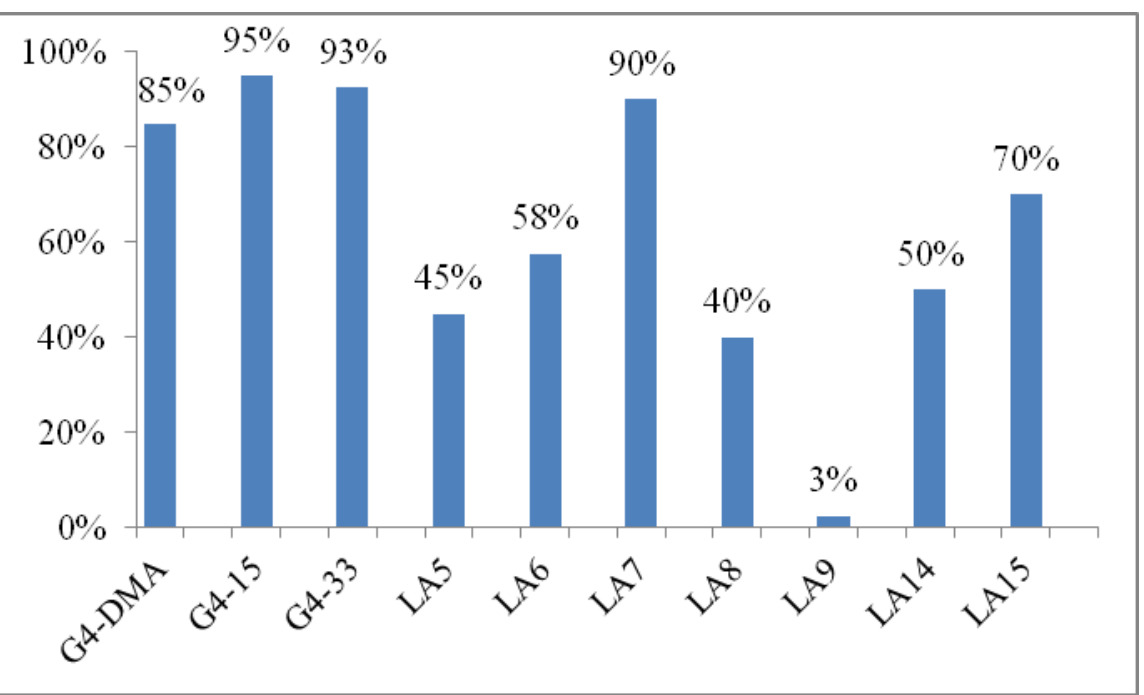

Chemicals 
Figure 2: Total OHSD scores per sector (\%).

_ Average OHSD score (Oil and Gas: 57\%; Construction: 60\%; Airlines: 46\%; Chemicals: 64\%)
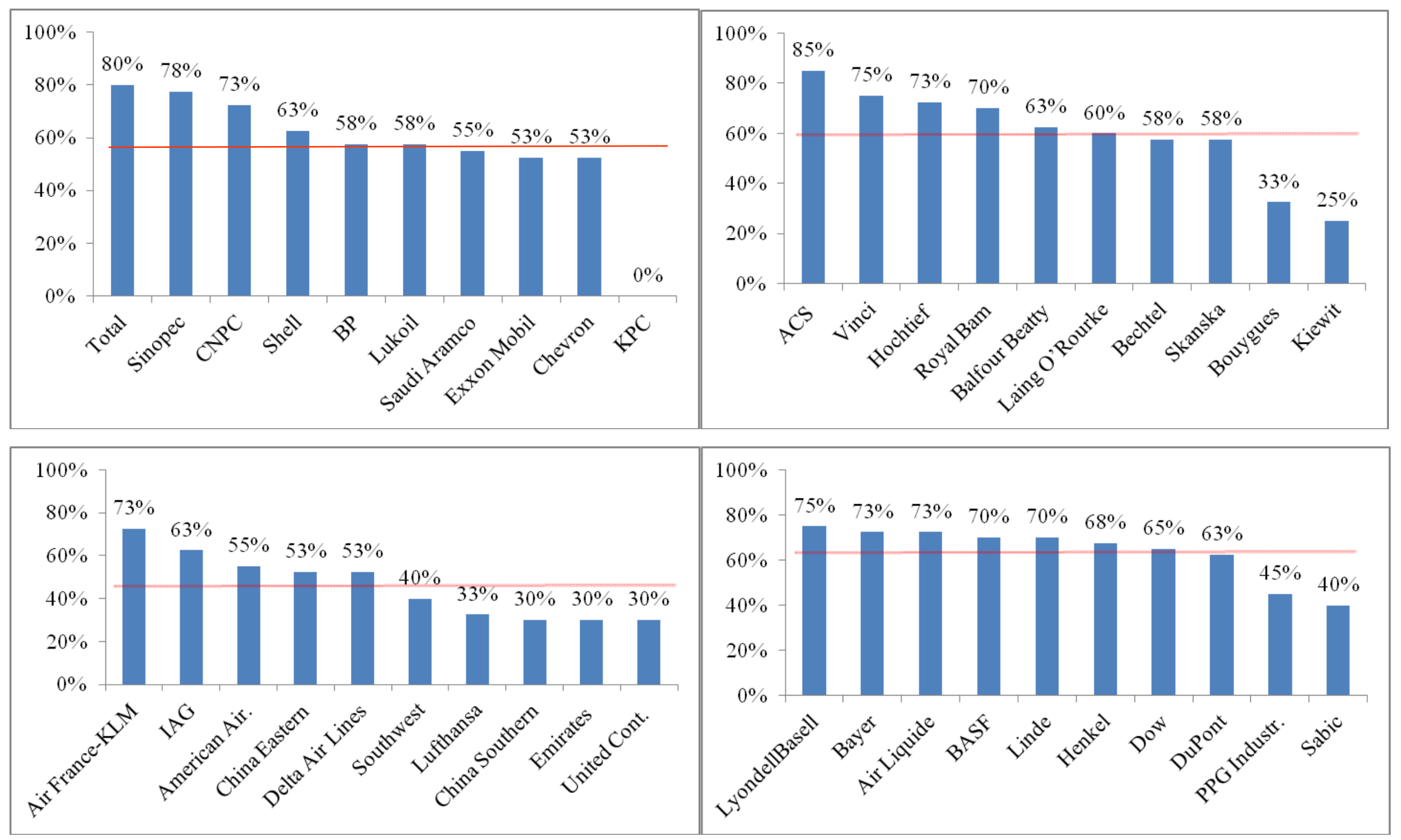
Figure 3: Line plot of the average OHSD broken down for the various sectors and regions

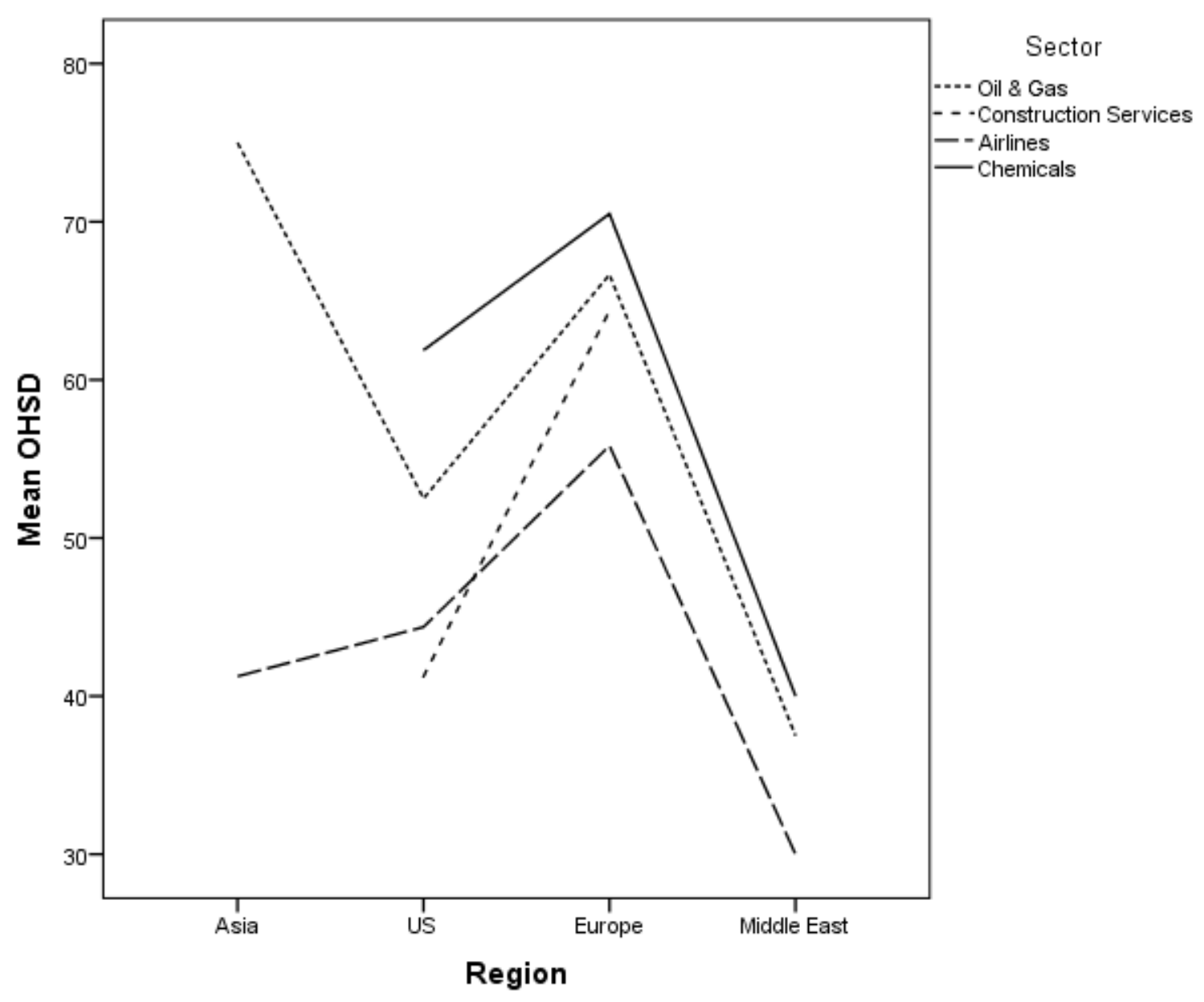


Figure 4: Scatter plot for the association between the OHSD index and international presence of companies, broken down by the different sectors

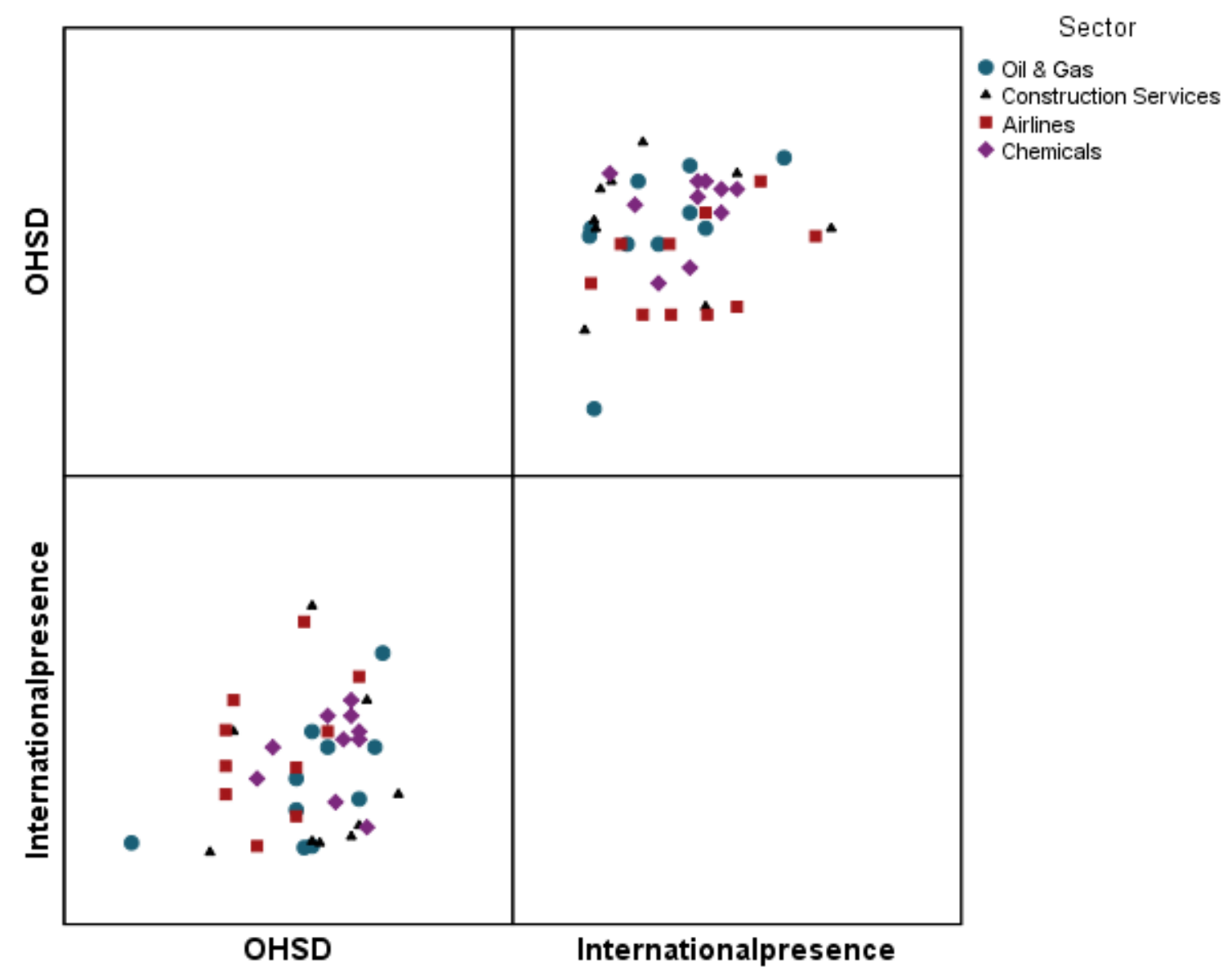


Figure 5: Scatter plot for the association between OHSD index and revenue, broken down by the different

sectors

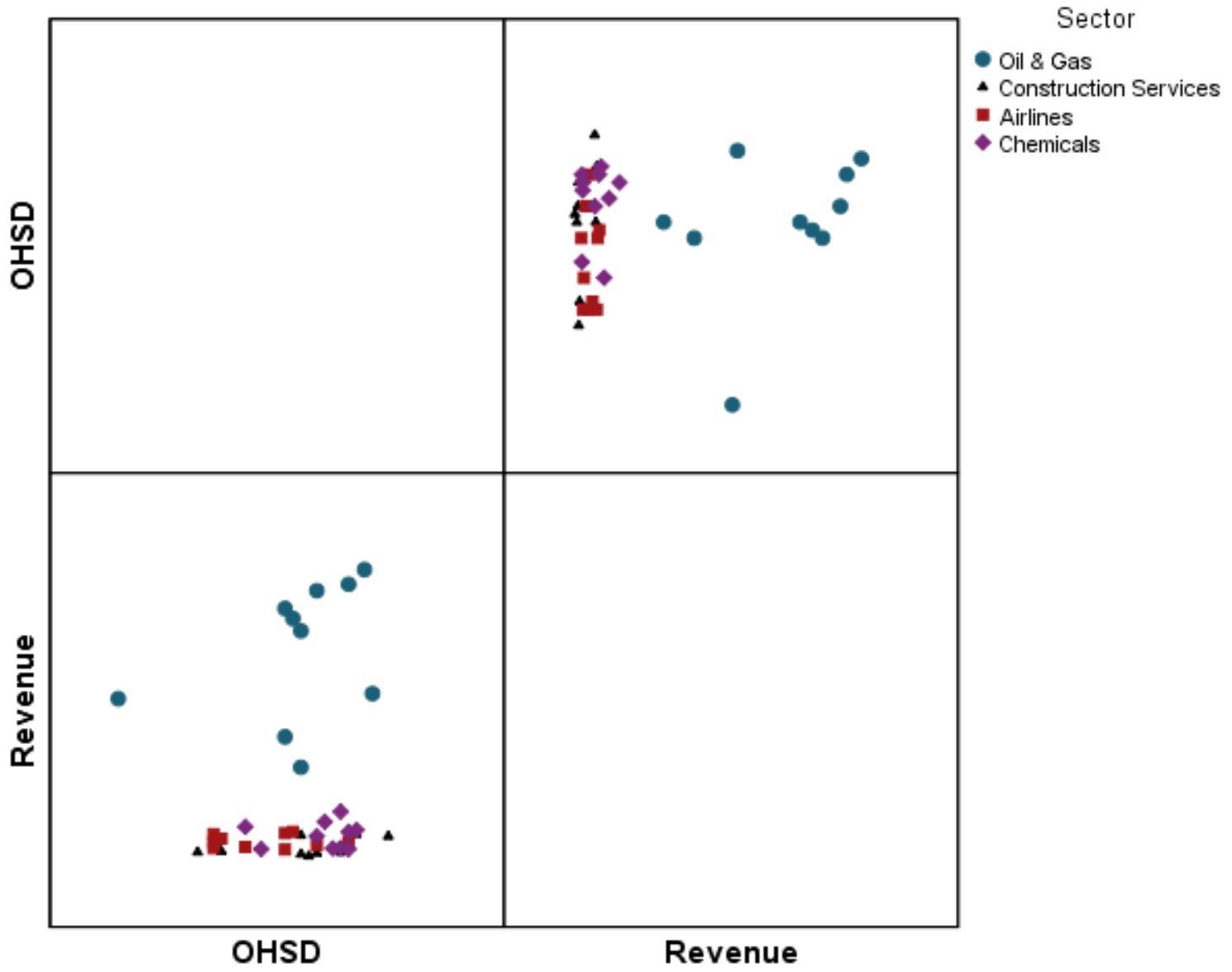


Figure 6: Scatter plot for the association between OHSD index and number of employees, broken down by the different sectors

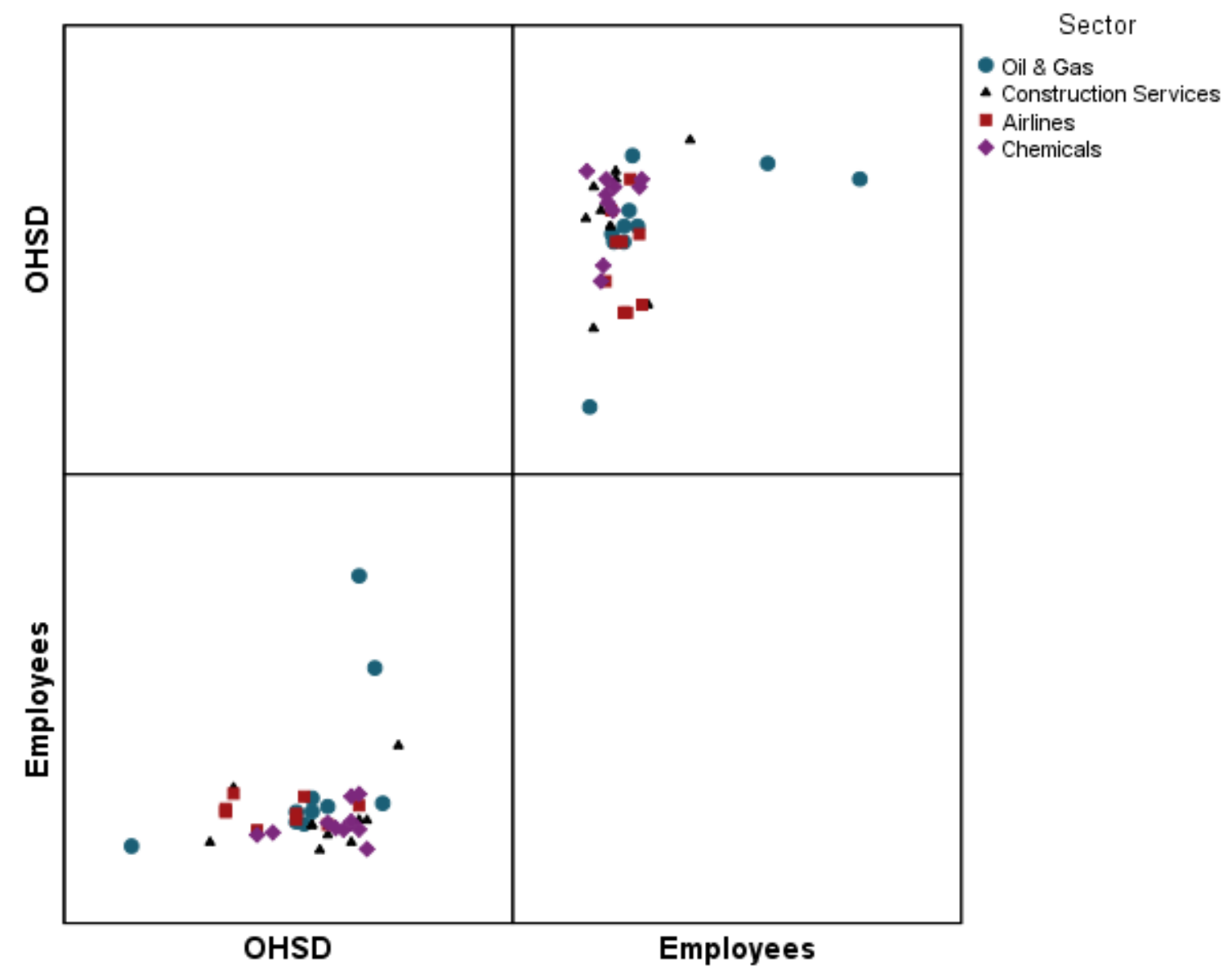


Figure A1: Scatter plot for the association between OHSD index and international presence of companies, broken down by the different regions

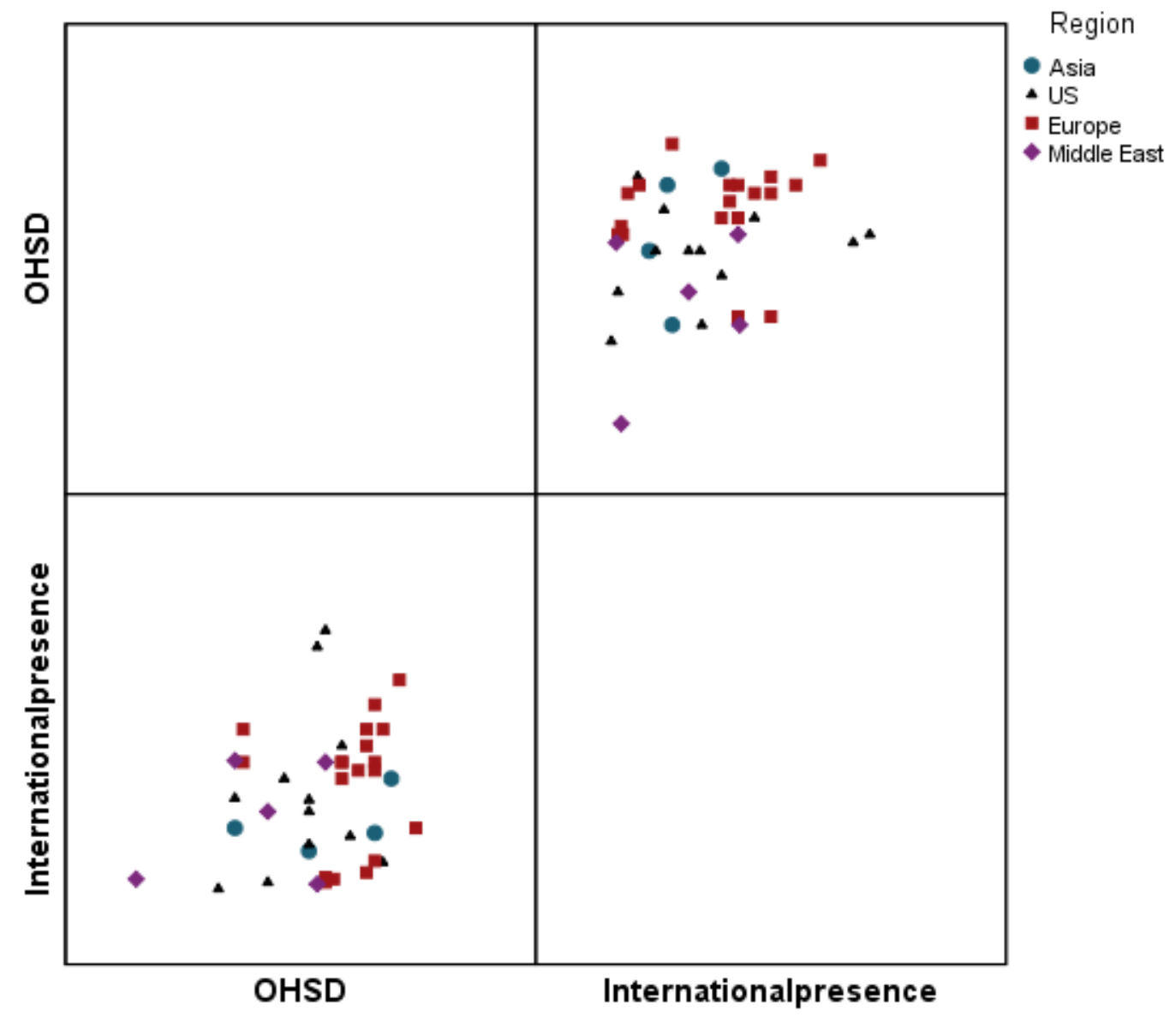


Figure A2: Scatter plot for the association between OHSD index and revenue of companies, broken down by the different regions

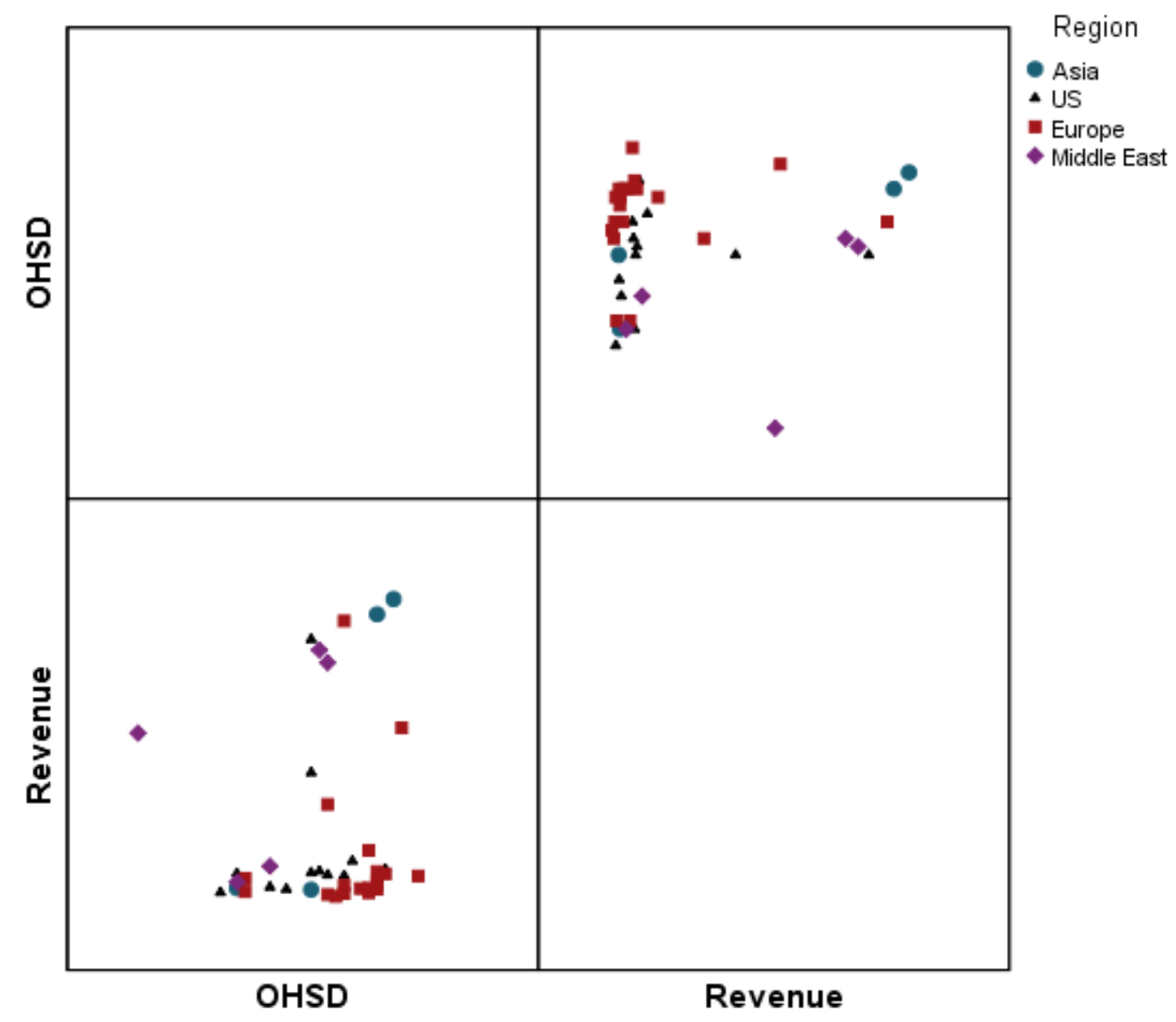


Figure A3: Scatter plot for the association between OHSD index and number of Employees, broken down by the different regions

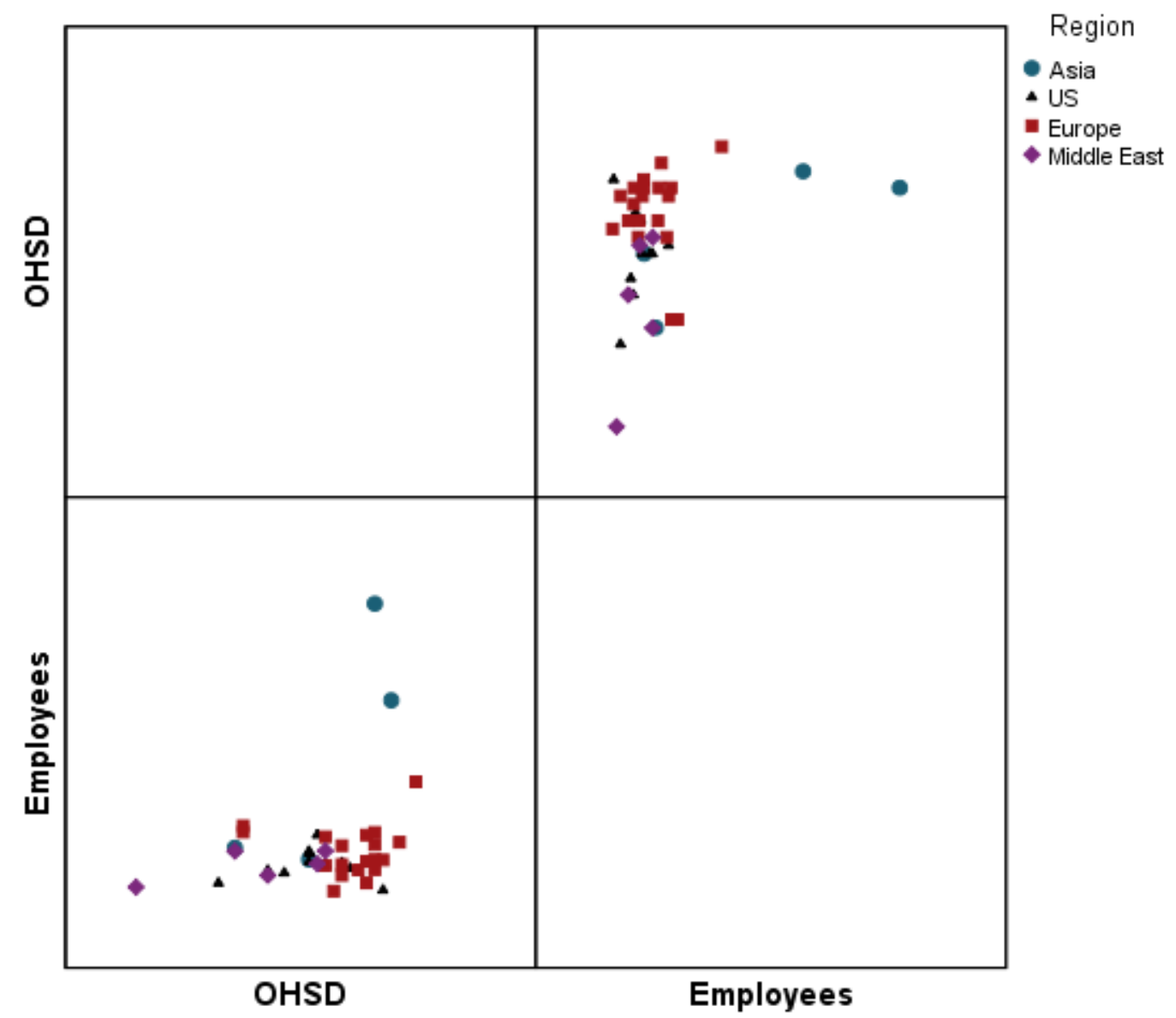


